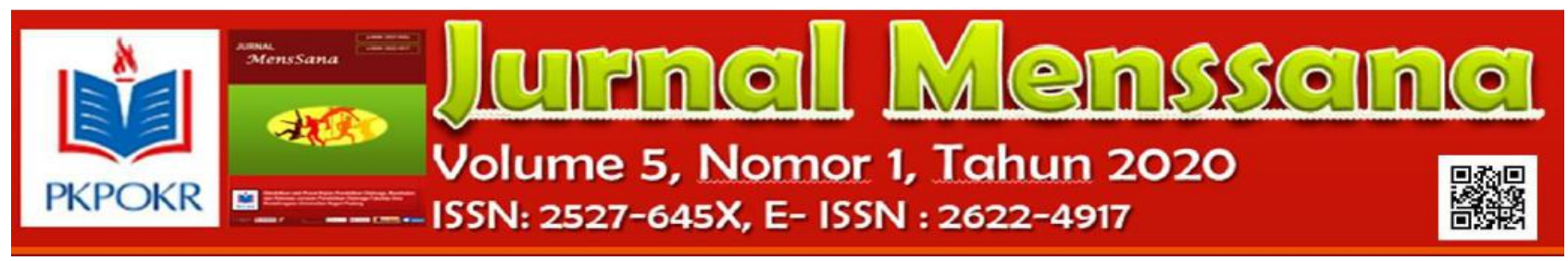

\title{
Analisis Karakteristik Psikologi Atlet Atletik Berdasarkan Nomor Event Lari, Lempar, dan Lompat
}

\author{
Adiska Rani Ditya Candra ${ }^{1}$, Kumbul Slamet Budiyanto ${ }^{2}$, Sobihin $^{3}$ \\ Jurusan Pendidikan Kepelatihan Olahraga, Fakultas Ilmu Keolahragaan Universiats Negeri Semarang, Gd. \\ F1, Lt. 3, Kampus FIK, UNNES, Sekaran, Gunungpati, Semarang, 50229, Indonesia
}

Coresponden Author. Email: Adiska rani@mail.unnes.ac.id

Menerima: 28 Maret 2020; Direvisi: 24 April 2020; Diterima: 26 April 2020



\begin{abstract}
Abstrak
Penelitian ini bertujuan untuk menganalisis karakteristik psikologi Atlet pada cabang olahraga Atletik serta membandingkan perbedaan antar nomor event yaitu nomor Lari, Lempar dan lompat. Penelitian dilakukan pada Atlet UKM Atletik Universitas Negeri Semarang dengan jumlah 27 Atlet Mahasiswa (11 Atlet Sprint, 6 Atlet Lari Jarak Panjang, 6 Atlet Lompat dan 6 Atlet Lempar). Instrumen penelitian yang digunakan yaitu instrumen PSIS-IR-5 (Psychological Skill Inventory For Sport) oleh Mahoney lalu diadopsi dan di kembangkan menjadi (PSIS-Youth-Cro) di Deutch (Sindik, Novokmet, \& Havas-Augustin, 2013). Hasil penelitian dapat ditarik kesimpulan bahwa analisis karakteristik Psikologi Atlet UKM Atletik meliputi terdapat faktor yang paling dominan dari 6 faktor yang diteliti yaitu Motivasi dan Percaya diri. Motivasi paling baik ditunjukkan oleh atlet lempar dan setelah diikuti oleh atlet lompat sprit dan atlet lari jarak jauh, Sedangkan faktor percaya diri paling baik dimiliki oleh atlet lari jarak menengah diikuti alet lempar, sprint dan lompat. Tidak ditemukan perbedaan yang signifikan dari masing-masing nomor event, pada faktor Kecemasan, Persiapan Mental, Motivasi, Perhatian Tim, Konsentrasi dan Percaya Diri. Ini dapat disimpulkan bahwa, Karakteristik Psikologi Atlet Atlet dari keempat nomor event tersebut tidak memiliki peredaaanberarti.
\end{abstract}

Kata Kunci : Atlet, Atletik, Karakteristik Psikologi.

\section{Abstract}

This study aims to analyze the psychological characteristics of Athletics athletes and compare the differences between each event number consisting of numbers running, throwing and jumping. The study was conducted at Semarang State University Athletes of Athletic Student Club with a total of 27 Student-Athletes (11 Sprinter, 6 Long Distance Running Athletes, 6 Jump Athletes and 6 Throw Athletes). The research instrument used was the PSIS-IR-5 (Psychological Skill Inventory For Sport5) by Mahoney and then was adopted and developed namely to become (PSIS-Youth-Cro) in Deutch (Sindik et al., 2013). The results of the study conclude the analysis of the Psychological Characteristics of Athlete Athletic student club are as follows: The most dominant factor of the 6 factors studied is Motivation and Confidence. Motivation is best shown by throwing athletes and after being followed by sprinters, jump athletes and long-distance runners, whereas the confidence factor is best possessed by intermediate distance athletes followed by throwing, sprint, and jumping athletes. No significant differences were found for each event number, on the factors of

This work is licensed by Lisensi Creative Commons Atribusi-BerbagiSerupa 4.0 Internasional, http://menssana.ppj.unp.ac.id/index.php/jm/issue/view/9 


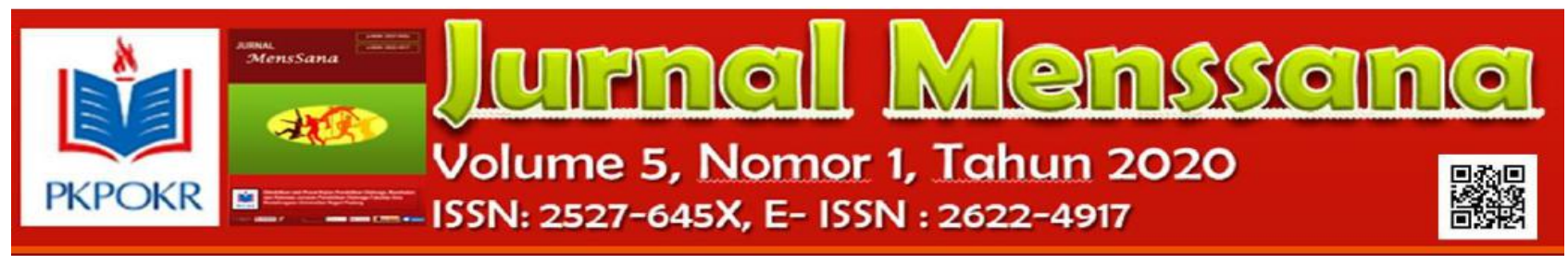

Anxiety, Mental Preparation, Motivation, Team Attention, Concentration, and Confidence. It was concluded that the Athletic Psychology Characteristics of the four-event numbers has no meaningful reduction.

Keywords:Athletes, Athletics, Characteristics Psychology

\section{PENDAHULUAN}

Ruang lingkup di dalam olahraga salah satunya termasuk untuk menggambarkan bagaimana memahami faktor psikologis yang mempengaruhi kinerja atlet dan bagaimana keterlibatan olahraga dan latihan berhubungan untuk perkembangan psikolgi, penyesuaian dan kesejahteraan (Willams dan Straub, 2010 dalam Galluci, 2014). Berkaitan dengan psikologi Olahraga, Weinberg dan Gould (1995, p.8) mengemukakan bahwa definisi dari psikologi olahraga adalah ilmu yang mempelajari tetang perilaku seseorang dalam berolahraga dan aktivitas latihannya. Ali maksum dalam bukunya menyatakan bahwa salah satu terapan ilmu psikologi dalam olahraga adalah pada latihan olahraga dan juga performa atau penampilan dalam olahraga. Aktivitas olahraga yang berperan dalam membentuk kepribadian berkontribusi untuk mengejarkan seseorang akan kedisiplinan, tidak mudah menyerah, jiwa sportifitas, mempunyai jiwa kompetitif, semangat yang tinggi dan berani dalam mengambil keputusan (Maksum, 2007)

Beberapa penelitian telah membuktikan peran psikologi sebagai penentu kinerja atlet serta membentuk kepribadian atlet. Weinberg \& Daniel, (2015) menjelaskan bawah personaliti atau kepribadian adalah sesuatu yang membuat seseorang itu unik. Pada dasarnya kepribadian merunjuk kepada karakteristik atau campuran dari karakteristik, dan itulah yang membuat seseorang itu unik (Weinberg \& Daniel, 2015). Karakteristik psikologi menunjukkan bagaimana diri atlet yang sesungguhnya. Selain itu menurut Brewer, 2009; Mirzaei, Nikbakhsh, \& Sharififar, 2013) kemampuan mempersiapkan mental dianggap sebagai komponen kunci perbedaan tersebut.

Durand-Bush \& Salmela, (2002)menyebutkan bahwa karakter karakteristik psikologis digunakan para atlet elit untuk meningkatkan prestasi, diantaranya adalah kepercayaan diri dan motivasi sebagai karakteristik yang paling menonjol. Pendekatan identifikasi karakteristik psikologis diperoleh dari faktor-faktor psikologis (DurandBush \& Salmela, 2002). Pendekatan ini untuk menyelidiki keterkaitan antara faktor psikologi dan kinerja untuk memeriksa pemain dewasa elit dan non elit (Mauris et all.,1993; Ikuleyo dan vipene, 1996). Asumsi yang mendasari pendekatan ini adalah remaja yang memiliki karakteristik di identifikasi sebagai keberhasilan penting dalam olahraga dewasa, dimana keberhasilan yang dimaksud adalah mempertahankan atribut ini hingga menjadi atlet dewasa yang sukses. Pendapat tersebut diperjelas oleh Morris, (2010) bahwa karakteristik yang penting untuk kesuksessan pada atlet dewasa dapat digunakan untuk mengidentifikasi psikologi remaja untuk seleksi awal.

Secara umum faktor-faktor psikologi yang dapat menentukan prestasi atlet yaitu faktor motivasi, percaya diri, kontrol kecemasan, perhatian, persiapan mental dan konsentasi. Davies dan Amstrong dalam Nopiyanto \& Dimyati, (2018) menyatakan bahwa faktor psikologi yang utama dan penting pada pencapaian prestasi atlet antara lain motivasi, konsnetrasi, percaya diri, dan persiapan mental. Teroi ini juga di konfirmasi oleh Mahoney: Dosil, (2006) yang menyebutkan bahwa aspek psikologis potensial serta memiliki pengaruh terhadap kinerja dan penampilan yakni kontrol kecemasan, motivasi, konsentrasi, percaya diri, persiapan mental, dan perhatian tim. Dimyati \& Hastuti, (2013) di dalam artikelnya menyebutkan bahwa beberapa peneliti telah menjelaskan pengaruh faktor psikologi terhadap penampilan atlet, seperti: 1) Myers, LeUnes, dan Bourgeois (1996) yang menyatakan bahwa atket elit rodeo mendapatkan skor lebih tinggi dari atlet non elit pada faktor Motivasi, konsentrasi dan control kecemasan; 2) Hasil studi Cox,Liu, dan Qiu(1996) pada atlet Cina Elit mendapatkan skor yang tinggi pada faktor Kontrol kecemasan dan Percaya diri; 3) Dosil, (2006) 




menjelaskan tentang perlunya dan pengaruh aspek psikologi pada atlet Bela diri (taekwondo, pencak silat dan lain-lain) adalah control emosi, konsentrasi, antisipasi, kepercayaan diri, control diri dan daya juang..

Kajian literatur yang menyebutkan bahwa adanya perbedaan terkait karakteristik psikologis pada Atlet dalam beberapa olahraga baik olahraga individu dan olahraga kelompok salah satunya adalah Dimyati \& Hastuti, (2013) dalam penelitiannya menegaskan bahwa secara umum karakteristik psikologi yang bermakna, namun terdapat perbedaan signifikan pada olahraga individu yaitu faktor kepercayaan diri, motivasi, perhatian tim pada cabor panahan dan pencak silat, Adanya perbedaan yang mendasar megenai karakteristik masing-masing cabang olahraga tersebut memungkinkan terjadinya perbedaan karakteristik Psikologi Atlet. Hasil penelitian menyebutkan bahwa olahraga individu memiliki aspek motivasi yang sangat tinggi dengan rerata sebesar 36,35 lalu diikuti aspek kepercayaan diri 26,51; kontol kecemasan 24,18; persiapan mental 21.32; pentingnya tim 15,17 ; dan tingkat konsentrasi yang tinggi dengan rerata sebesar 22,30 (Nopiyanto \& Dimyati, 2018).

Hal ini tentu menjadi kajian yang penting untuk ditinjau lebih lanjut terkait atlet pada cabang olahraga Atletik pada setiap nomor terkhusus pada Atlet UKM Atletik Universitas Negeri Semarang. Berdasarkan hasil wawancara kepada Atlet Atletik UKM UNNES dan pengalaman peneliti banyak atlet yang belum paham mengenai bagaimana faktor psikologi yang dirasakan oleh atlet baik dalam berlatih maupun bertanding. Atlet Atletik hanya mengerti akan rasa gugup, cemas, tidak fokus dan memiliki sikap optimis dalam setiap hal yang dilakukan. Berdasarkan pengalaman penulis juga tidak adanya program latihan mental yang digunakan untuk meningkatkan mental atlet untuk prestasi penunjangnya. Padahal pentingnya pengaruh psikologis bagi performa atlet baik dalam latihan ataupun saat sedang bertanding. Beberapa atlet UKM Atletik mengalami penurunan padahal profil beberapa atlet pernah memiliki prestasi pada tingkat regional maupun nasional $\mathrm{Hal}$ ini lah yang patut ditingkatkan dari segi latihan baik secara fisik, teknik, taktik dan juga mental.

Berdasarakan aspek psikologi yang berpengaruh terhadap penampilan atlet baik saat bertanding maupun berlatih di berbagai cabang olahraga. Tujuan utama dalam penelitian ini adalah untuk memeriksa karakteristik psikologis atlet Atletik UKM di Universitas Negeri Semarang yang dianggap telah berkontribusi terhadap prestasi yang meraka pernah raih. Pengetahuan pemahaman tentang karakteristik psikologi bagi pelatih ataupun pembina UKM penting untuk diketahui yang didasari dengan berbagi perbedaan baik jenis kelamin, karakteristik dari nomor-nomor dari olahraga Atletik ini yang akan mendukung penampilan atlet UKM Atletik di daerah, nasional, bahkan Internasional. Cabang olahraga Atletik memiliki nomor event tertentu yang mana karakteristik dari masing-masing nomor akan dilihat baik dalam nomor lari, lempar dan lompat. Ada 6 faktor psikologi yang akan dilihat sesuai dengan questioner yang akan digunakan, yaitu Anxiety Control; Confidence; Motivation; Consentration; Team Emphasis; Mnetal Preparation

\section{METODE}

Metode penelitian menggunakan metode survei ex post facto dengan pendekatan deskriptif kuantittatif. Hal ini digunakan untuk memberikan gambaran lebih detail dengan mengidentifikasi faktor-faktor karateristik atlet pada cabang olahraga Atletik di UKM Atletik Universitas Negeri Semarang. Populasi dalam penelitian ini berjumlah 27 atlet dengan yang terdiri dari 17 atlet lari, 6 atlet lompat dan 6 atlet lempar dan seluruhnya digunakan sebagai sampel.

Instrumen yang digunakan dalam penelitian ini yaitu instrumen PSIS-IR-5 (Psychological Skill Inventory For Sport) oleh (Mahoney, Gabriel, \& Perkins, 1988) dan diadopsi serta dikembangkan pada Negara Deutch yaitu menjadi (PSIS-Youth Cro) (Sindik et al., 2013). Itu memuat 43 pertanyaan/point dengan perhitungan skala likert, dibagai kedalam 5 skala yang sama pada (PSIS-IR-5) yakni; Motivation ( 7 items), Anxiety Control (8 


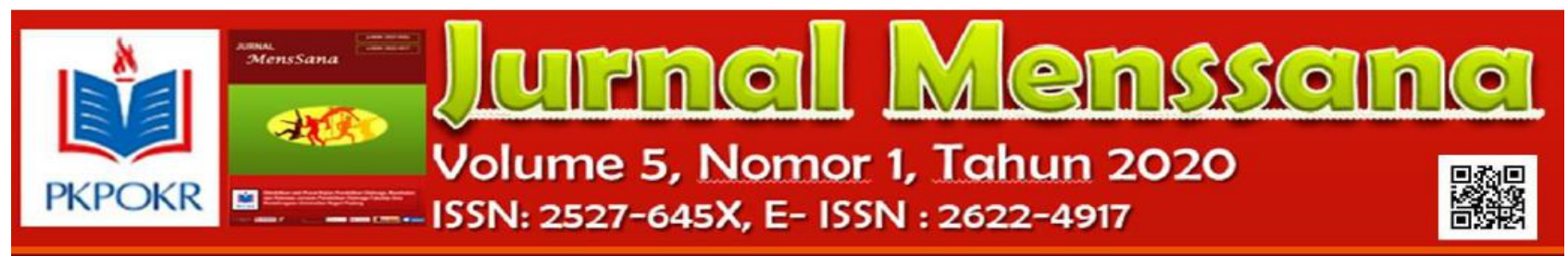

items), Concentration(7 items), Mental Preparation (6 items), Team Emphasis (6 Items), and Confidence( 8 items). Instrumen ini telah diuji dengan nilai reliabilitas yang cukup tinggi yaitu pada angka 0,8 hingga 0,9 dengan perhitungan Cronbach's Alpha.

Tahapan penelitian yang akan dilaksanakan adalah sebagai berikut: 1) menerjemahkan instrumen dari bahasa Inggris ke bahasa Indonesia, 2) proses validitas keabsahan instrumen yang divalidasi oleh ahli pada bidang Psikologi Olahraga, 3) pengambilan data, 4) menganalisis data, 5) sintesis data untuk dapat digunakan sebagai referensi pelatih dan masukan bagaimana karakteristik psikologis ini berpengaruh terhadap performa atlet,

Analisis data menggunakan analisis statistic deskriptif yang digunakan untuk mendeskripsikan karakteristik psikologi atlet. Pengukuran dengan distribusi kedalam 5 Five-point likert scale. Rumus yang digunakan untuk mencari presentase dan kelas interval yakni :

Tabel 1. Penghitungan Kelas Interval

\begin{tabular}{lc}
\hline \multicolumn{1}{c}{ Interval Skor } & Kategori \\
\hline Diatas (Mi + 1,8SD) s.d (Mi+3SD & Very High \\
Diatas (Mi 0,6) s.d (Mi + 1,8SD) & High \\
Diatas (M-0,6SD) s.d (Mi+0,6SD) & Sedang \\
Diatas (Mi-1,8SD) s.d (Mi-0,6SD) & Kurang \\
(Mi-3SD) s.d (Mi-1,8SD) & Sangat Kurang \\
\hline
\end{tabular}

\section{HASIL DAN PEMBAHASAN}

HASIL

Hasil Analisis Deskriptif Data Atlet UKM Atletik
Hasil dari analisis yang didapatkan dari perhitungan prosentase dan rerata skor dan standar deviasi yang ditunjukkan pada tabel nomor 2,3,4,5 dan 6. Tabel hasil menunjukkan hasil perolehan rerata dari masing-masing nomor event terhadap faktor-faktor psikologi yang menjadi butir-butir pada instrumen PSIS-R-5.

Berdasarkan pengujian analisis deskriptif menggunakan SPSS 18 (PASW Statistics 18), maka didapatkan hasil pada tabel berikut:

Tabel 2. Statistik Deskriptif Aspek Psikologi Atlet UKM Atletik

\begin{tabular}{lccc}
\hline Karakteristik Psikologi & N & Mean & $\begin{array}{c}\text { Std. } \\
\text { Deviation }\end{array}$ \\
\hline Anxiety Control & 29 & 25,86 & 5,945 \\
Confidence & 29 & 29,38 & 3,610 \\
Mental Preparation & 29 & 22,00 & 4,053 \\
Motivation & 29 & 33,07 & 2,463 \\
Team Emphasis & 29 & 20,66 & 2,991 \\
Concentration & 29 & 22,38 & 2,744 \\
Valid N (listwise) & 29 & & \\
\hline
\end{tabular}

Berdasarkan hasil pada tabel 2, total keseluruhan responden dalam penelitian ini sejumlah 29 atlet. Data menyatakan skor terendah untuk aspek anxiety control sebesar 15, nilai tertinggi 37 dengan rata - rata aspek anxiety control 25,86 . Nilai tertinggi untuk aspek confidence adalah 39 dan nilai terendah 23 dengan rata - rata pada aspek confidence 29,38. Nilai terendah untuk aspek mental preparation sebesar 14 dan nilai tertinggi 30 dengan rata - rata pada aspek mental preparation 22,00 . Selanjutnya nilai terendah untuk aspek motivation sebesar 25 dan nilai tertinggi 35 dengan rata - rata sebesar33,07. Nilai terendah untuk aspek team emphasis sebesar 16 dan nilai tertinggi 26 dengan rata - rata team emphasis sebesar20,66. Nilai terendah untuk aspek concentration sebesar 16, nilai tertinggi 27 dengan rata - rata motivation 22,38 . 


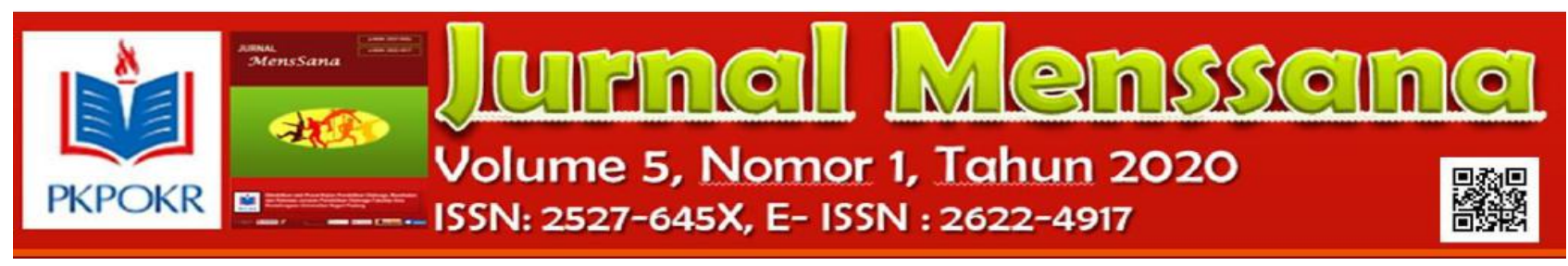

Tabel 3. Analisis Deskriptif Karakteristik Psikologis Atlet Lari Jarak Pendek

\begin{tabular}{lcccc}
\hline \multirow{2}{*}{ Nomor/ Event } & \multicolumn{4}{c}{ Lari Jarak Pendek } \\
\cline { 2 - 5 } Aspek Psikologis & Rerata & SD & Kategori & Prosentase \\
Anxiety Control & 23,73 & 6,182 & Sedang & $59,32 \%$ \\
Mental Preparation & 22,91 & 3,910 & Sedang & $57,27 \%$ \\
Motivation & 32,82 & 3,060 & Sangat Tinggi & $82,04 \%$ \\
Team Emphasis & 22,27 & 2,936 & Sedang & $55,68 \%$ \\
Concentration & 22,64 & 3,472 & Sedang & $56,59 \%$ \\
Confidence & 28,73 & 4,315 & Tinggi & $78,40 \%$ \\
\hline
\end{tabular}

Berdasarkan output pada tabel 3 didapatkan hasil yakni atlet lari Jarak pendek dengan jumlah 11

atlet memiliki motivasi yang sangat tinggi dengan rerata sebesar 32,82 dan prosentase sebesar 82,04\%. Selanjutnya pada aspek
Confidence dengan kategori tinggi dengan prosentasie $78,40 \%$, diikuti oleh aspek anxiety control 59.32\% kategori sedang. Lebih dari separuh yaitu $57,27 \%$ memiliki mental preparation yang sedang. Sedangkan pada aspek concentration prosentase $56,59 \%$ dan team emphasis dengan kategori sedang dan prosentase sebesar $55,68 \%$

Tabel 4. Analisis Deskriptif Karakteristik Psikologis Atlet Lari Jarak Menengah/Jauh

\begin{tabular}{lllll}
\hline \multirow{2}{*}{ Nomor/ Event } & \multicolumn{4}{c}{ Lari Jarak Menengah/Jauh } \\
\cline { 2 - 5 } & Mean & SD & Kategori & Prosentase \\
\hline Aspek Psikologis & 27,50 & 6,504 & Tinggi & $68,75 \%$ \\
Anxiety Control & 19,67 & 1,966 & Sedang & $49,17 \%$ \\
Mental Preparation & 32,00 & 3,060 & Sangat Tinggi & $80 \%$ \\
Motivation & 18,33 & 2,582 & Sedang & $45,83 \%$ \\
Team Emphasis & 23,17 & 2,639 & Sedang & $57,92 \%$ \\
Concentration & 30.00 & 2,366 & Sangat Tinggi & $80 \%$ \\
Confidence & & & & \\
\hline
\end{tabular}

Berdasarkan tabel 4 menunjukkan bahwa atlet lari jarak menengah jauh yang berjumlah 6 orang, memiliki motivasi dan confidence yang sangat tinggi sebesar $80 \%$, diikuti oleh aspek anxiety control dengan prosentase $68,75 \%$ dan kategori tinggi. Pada aspek concentration menunjukkan kategori sedangn dengan prosentase sebesar 57,92\%. Selanjutnya aspek mental preparation $49,17 \%$ sedang dan pada aspek Team Emphasis kategori sedang pada $45,83 \%$.

Tabel 5. Analisis Deskriptif Karakteristik Psikologis Atlet lompat

\begin{tabular}{lcccc}
\hline \multirow{2}{*}{ Nomor/ Event } & \multicolumn{3}{c}{ Lompat } \\
\cline { 2 - 5 } & \multicolumn{4}{c}{$\mathbf{N}=\mathbf{6}$} \\
\hline Aspek Psikologis & Rerata & SD & Kategori & Prosentase \\
Anxiety Control & 25,67 & 6,532 & Tinggi & $64,17 \%$
\end{tabular}




\section{道:}

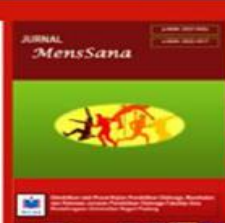

Iutrinal

Menssana

Volume 5, Nomor 1, Tahun 2020

ISSN: 2527-645X, E- ISSN : 2622-4917

Mental Preparation
Motivation
Team Emphasis
Concentration
Confidence

Berdasarkan table 5 bahwa atlet Lompat memiliki motivasi sangat tinggi dengan prosentase $84,17 \%$, diikuti oleh aspek Confidence dan Anxiety Control dengan prosentase berturut-turut sebesar 73,33\% dan $64,17 \%$ dengan kategori tinggi. Sebesar 57,91\%
23,17

33,67

20,17

21,00

23,17

$\begin{array}{ll}4,764 & \text { Sedang } \\ 1,366 & \text { Sangat Tinggi } \\ 2,483 & \text { Sedang } \\ 2,191 & \text { Sedang } \\ 4,764 & \text { Tinggi }\end{array}$

Tabel 6. Analisis Deskriptif Karakteristik Psikologis Atlet Lempar

\begin{tabular}{lllll}
\hline \multirow{2}{*}{ Nomor / Event } & \multicolumn{3}{c}{ Lempar } \\
\cline { 2 - 5 } & \multicolumn{4}{c}{$\mathbf{N = 6}$} \\
\hline Aspek Psikologis & Mean & SD & Kategori & Prosentase \\
\hline Anxiety Control & 28,33 & 3,983 & Tinggi & $70,83 \%$ \\
Mental Preparation & 21,50 & 2,764 & Sedang & $53,75 \%$ \\
Motivation & 34,00 & 1,265 & Sangat Tinggi & $85 \%$ \\
Team Emphasis & 18,33 & 2,582 & Sedang & $51,25 \%$ \\
Concentration & 23,17 & 2,639 & Sedang & $56,25 \%$ \\
Confidence & 30,00 & 2,608 & Tinggi & $75 \%$ \\
\hline
\end{tabular}

Berdasarkan output pada tabel 3. Didapatkan hasil bahwa atlet lempar memiliki motivasi sangat tinggi dengan an prosentase $85 \%$, diikuti oleh aspek Confidence dan Anxiety Control dengan kategori tinggi dan prosentase berturut-turut sebesar $75 \%$ dan $70,83 \%$. Selanjutnya pada aspek mental preparation dan concentration pada kategori sedang dan prosentase sebesar 56,25\%. Lalu 51,25\% aspek Team Emphasis dengan kategori sedang .

Data yang telah ditunjukkan pada tabel 3 hingga tabel 6 diketahui dan dapat dianalisis bahwa Atlet Atletik UKM Unnes berdasarkan memiliki aspek mental preparation yang sedang. Selanjutnya sebesar 52,5\% pada aspek concentration pada kategori sedang. Sedangkan pada aspek Team Emphasis menunjukkan kategori sedang dengan prosentase sebesar $50,42 \%$.
$57,91 \%$

$84,17 \%$

$50,42 \%$

$52,5 \%$

$73,33 \%$ 


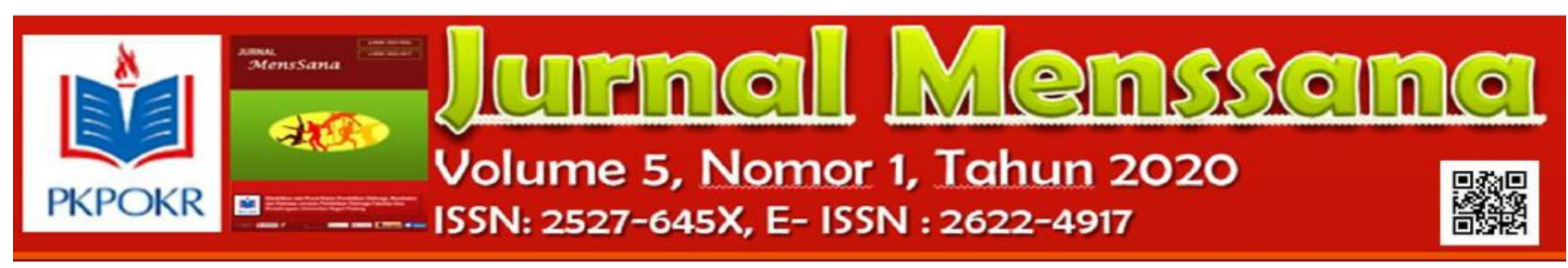

Hasil Uji Normalitas

Tabel 7. Hasil Uji Normalitas Data Karakteristik Atlet menggunakan One-Sample KolmogorovSmirnov Test

\begin{tabular}{|c|c|c|c|c|c|c|c|}
\hline & & $\begin{array}{l}\text { Anxiety } \\
\text { Control }\end{array}$ & Confidence & $\begin{array}{c}\text { Mental } \\
\text { Preparation }\end{array}$ & Motivation & $\begin{array}{c}\text { Team } \\
\text { Emphasis }\end{array}$ & Concentration \\
\hline \multicolumn{2}{|l|}{$\mathrm{N}$} & 29 & 29 & 29 & 29 & 29 & 29 \\
\hline \multirow{2}{*}{$\begin{array}{l}\text { Normal } \\
\text { Parametersa,b }\end{array}$} & Mean & 25,86 & 29,38 & 22,00 & 33,07 & 20,66 & 22,38 \\
\hline & $\begin{array}{l}\text { Std. } \\
\text { Deviation }\end{array}$ & 5,945 & 3,610 & 4,053 & 2,463 & 2,991 & 2,744 \\
\hline \multirow{3}{*}{$\begin{array}{l}\text { Most Extreme } \\
\text { Differences }\end{array}$} & Absolute &, 123 &, 120 & , 127 & ,233 &, 144 &, 171 \\
\hline & Positive &, 071 &, 120 & , 127 & 217 &, 144 & , 152 \\
\hline & Negative &,- 123 &,- 078 &,- 092 &,- 233 &,- 144 &,- 171 \\
\hline \multicolumn{2}{|c|}{ Kolmogorov-Smirnov Z } & 663 & ,645 & ,682 & 1,257 & ,776 & ,920 \\
\hline \multicolumn{2}{|c|}{ Asymp. Sig. (2-tailed) } & ,771 & ,799 & ,740 & 085 & ,584 & ,365 \\
\hline
\end{tabular}

Berdasarkan hasil pada Tabel 7. One Sample Kolmogorov - Smirnov Test, didapatkan hasil Asymp.Sig $(2-$ tailed $)$ untuk variabel anxiety control sebesar 0,771, variabel confidence sebesar 0,799 , variabel mental preparation sebesar 0,740 , variabel motivation sebesar 0,085, variabel team emphasis sebesar 0,584 , dan variabel concentration sebesar 0,365. Berdasarkan nilai Asymp.Sig ( 2 - tailed) yang dihasilkan untuk setiap karakteristik psikologi yang diukur, dengan menggunakan taraf kepercayaan $0,05(\alpha=5 \%)$, maka $H_{0}$ diterima atau dapat disimpulkan semua variabel memiliki status distribusi normal.

\section{Hasil Uji Homogenitas}

Tabel 8. Hasil Uji Homogentas menggunakan Levente's Test of Equality of Error Variances ${ }^{\mathrm{a}}$

\begin{tabular}{lrrrr}
\hline \multicolumn{1}{c}{$\begin{array}{c}\text { Karakteristik } \\
\text { Psikologis }\end{array}$} & F & df1 & df2 & Sig. \\
\hline Anxiety Control &, 283 & 3 & 25 & 0,837 \\
Confidence &, 700 & 3 & 25 & 0,561 \\
Mental Preparation &, 943 & 3 & 25 & 0,435 \\
Motivation & 1,602 & 3 & 25 & 0,214 \\
Team Emphasis &, 400 & 3 & 25 & 0,754 \\
Concentration & 1,533 & 3 & 25 & 0,231 \\
\hline
\end{tabular}

Berdasarkan pada Tabel Levente's Test of Equality of Error Variances, diketahui bahwa nilai Sig. untuk variabel anxiety control sebesar
0,837, confidence sebesar 0,561, mental preparation sebesar 0,435 , motivation sebesar 0,214, team emphasis sebesar 0,754, dan concentratio sebesar 0,231. Dikarenakan nilai Sig. untuk setiap variabel lebih dari 0,05 $(\alpha=$ $5 \%$, maka $H_{0}$ diterima, dan dapat disimpulkan bahwa varians pada setiap variabel sama untuk semua group.

\section{Hasil Uji Analisis Varians}

Hasil analisis Multivariate dari karakteristik psikologi atlet Atletik berdasarakan nomor event yakni lari jarak menengah/jauh, lari sprint atau lari jarak pendek, lompat serta lempar yang telah diujikan untuk menguji apakah setiap faktor (event) mempengaruhi grup variabel dependen (karakteristik psikologis). Berdasarkan pada hasil uji Multivariate Tests, Sig. pada Wilk's Lambda dengan nilai $\mathrm{F}$ hitung 0,081 dimana Sig. yang dihasilkan lebih dari 0,05 $(\alpha=5 \%)$. Hasil menunjukkan bahwa tidak terdapat hubungan antar event yakni lari jarak menengah/jauh, lari sprint atau lari jarak pendek, lompat serta lempar dengan karakteristik psikologis yang diukur.

Untuk mengukur analisis masing-masing karakteristik Psikologi tehadap setiap event dapat dilihat pada tabel 9 dengan menggunak test of between-Subject Effect 




Tabel 9. Rangkuman Hasil analisis Multivariat Setiap Karakteristik Psikologi Atlet ditinjau dari masingmasing nomor event

\begin{tabular}{|c|c|c|c|c|}
\hline $\begin{array}{c}\text { Karakteristik } \\
\text { Psikologi }\end{array}$ & $\begin{array}{c}\text { Type III } \\
\text { Sum of } \\
\text { Squares }\end{array}$ & $\begin{array}{c}\text { R } \\
\text { Squaare }\end{array}$ & $\mathbf{F}$ & Sig \\
\hline $\begin{array}{l}\text { Anxiety } \\
\text { Control }\end{array}$ & 103,100 & 0.104 & 0,969 & 0,423 \\
\hline Confidence & 9,312 & 0,026 & 0,218 & 0,883 \\
\hline $\begin{array}{c}\text { Mental } \\
\text { Preparation }\end{array}$ & 51,424 & 0,112 & 1,049 & 0,388 \\
\hline Motivation & 14,892 & 0,088 & 801 & ,505 \\
\hline $\begin{array}{c}\text { Team } \\
\text { Emphasis }\end{array}$ & 62,703 & 0,250 & 2,782 &, 062 \\
\hline Concentration & 15,949 & 0,076 & ,682 &, 571 \\
\hline
\end{tabular}

Beradasarkan tabel no. 9 pada hasil uji Test of Between Subject Effects didapatkan hasil sebagi berikut. Aspek Anxiety Control diketahui bahwa nilai Sig. sebesar 0,423. Pada Aspek Confidence didapatkan hasil nilai Sig. untuk varibel confidence sebesar 0,883. Sedangkan pada Aspek Mental Preparation nilai Sig. sebesar 0,388. Pada Aspek motivation nilaiSig. sebesar 0,505 . Selanjutnya nilai Sig. untuk aspek team emphasis sebesar 0,062. Nilai Sig. untuk aspek concentration sebesar 0,571. Dari data diketahui bawah Sig. $>\alpha$ atau Sig. $>0,05$ pada seluruh karateristik psikologi, maka $H_{0}$ diterima atau disimpulkan bahwa tidak ada perbedaan yang berarti atau perbedaan yang signifikan pada karaketristik psikologi aspek confidence, anxiety control, motivation, mental preparation, concentration dan team emphasis pada setiap nomor event dalam cabang olahraga Atletik (lari sprint atau lari jarak, lari jarak menengah dan jauh, lompat serta lempar).

\section{PEMBAHASAN}

Deskripsi Karakteristik Psikologi Atlet Cabang olahraga Atletik di UKM Atletik Universitas Negeri Semarang

Berdasarkan hasil analisis data karakteristik psikologi dan juga dikutip dari hasil penelitian sebelumnya yang sudah di publish sebesar 50\% pada Proceeding ACPES 2019 oleh peneliti bahwa yang menjadi variable penelitian yakni aspek motivasi lebih dominan terhadap atlet Atletik nomor lari sprint atau lari jarak, lari jarak menengah dan jauh, lompat serta lempar dengan masing-masing menunjukkan kategori sangat tinggi. Tentu hal ini menjadi awal keberhasilan yang baik jika seorang atlet memiliki motivasi yang baik.

Beberapa aspek psikologi yang lain lebih cenderung ke kategori tinggi dengan prosentase lebih dari separuh atau $50 \%$ yaitu pada aspek Confidence, Anxiet Control, namun di beberapa aspek Mental Preparation, Concentration serta Team Emphasis menunjukkan kategori sedang bahkanl cenderung rendah.

Dalam pembahasan ini cukup menarik perhatian bahwa motivasi sangat tinggi namun ternyata hal ini tidak memiliki dampak yang baik terhadap aspek yang lain seperti konsentrasi yang seharusnya mutlak dimiliki oleh atlet pada umumnya. Setiap nomor dalam cabang olahraga Atletik sangatlah membutuhkan konsentrasi, seperti start pada saat akan lari, fase persiapan saat akan memulai gerakan lompat dan lempar, karena segala sesuatu memiliki tahapan persiapan dalam cabang olahraga atletik tentu jika kehilangan konsentrasi maka gerakan yang akan dilakukan tidak dapat maksimal, sebagai contoh dampak pelari jika tidak memiliki konsentrasi yang cukup maka akan terlambat dalam pelaksanaan start akibanya pastilah langkah pertama akan tertinggal sepersekian detik oleh pelari yang lain dimana ini akan sangat merugikan bagi atlet itu sendiri. Hal ini sependapat dengan Dossil bahwa :

"Attention and Concentration in Athletics Concentration is an important variable in every period of the athletics season : to achieve established objectives in training; to combine the attentional demand of training and competition in the minor competition phase"(Dosil, 2006b).

Dalam bukunya, dossil juga sangat menekankan kharateristik psikologi yang harus ditekankan pada nomor-nomor lari, baik lari sprint, middle distance, long distance, marathon hingga hurdle. Salah satu penekanan yang perlu 


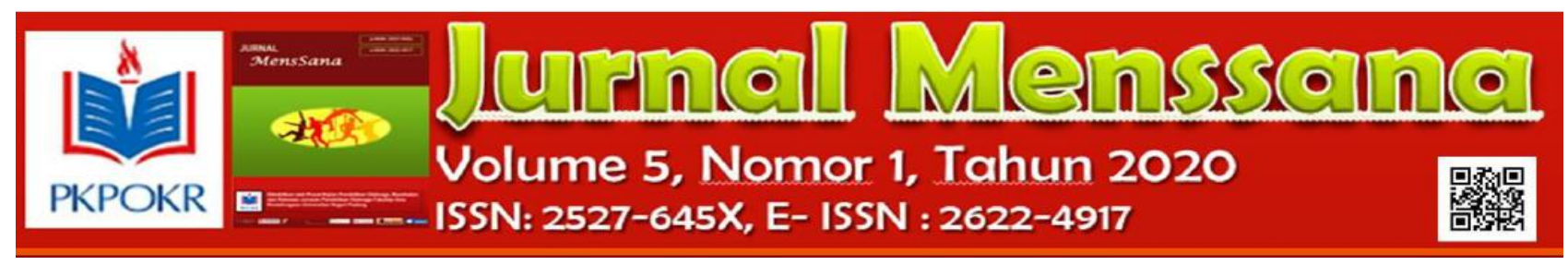

penerapan concentration secara berturut-turut atau secara terus menerus adalah sebagai berikut:

" $100 \mathrm{~m}$ and $110 \mathrm{~m}$ hurdles As with the sprint events, getting a good start is essential. Therefore, we can apply the characteristics described for the $100 \mathrm{~m}$ and $200 \mathrm{~m}$ events are applicable here. These disciplines require continuous concentration, since although it is permitted to knock over hurdles, the time and technique lost can affect the result and the athlete's self-confidence "(Dosil, 2006b).

Selain konsentrasi dan motivasi, aspek psikologi atlet atletik yang lain juga perlu untuk ditekankan karena walaupun pada hasil penelitian beberapa atlet memiliki kategori tinggi namun masih ada beberapa atlet yang memiliki kategori sedang bahkan rendah pada aspek mental preparation dan team emphasis (Candra, Budiyanto, \& Sobihin, 2019).

\section{Analisis Multivariat Karakteristik Psikologi}

Berdasarkan hasil analisis multivariat karakteristik psikologi pada setiap nomor dalam cabang olahraga atletik (lari jarak pendek, lari jarak menengah - jauh, lompat, dan lempar) menujukkan bahwa nilai nilai $\mathrm{F}$ hitung 0,081 dimana Sig. yang dihasilkan lebih dari 0,05 $(\alpha=5 \%)$. Hal ini menunjukkan bahwa tidak terdapat hubungan antara event yang terdiri dari lari jarak pendek, lari jarak pendek, lari jarak menengah - jauh, lompat, dan lempar dengan karakteristik psikologis yang diukur. Lalu bagaimana dengan uji hipotesis setiap variabel aspek Psikologi pada setiap nomor? Hasil analisis pada setiap Aspek Psikologi yakni confidence, anxiety control, motivation, mental preparation, concentration dan team emphasis terhadap event dalam atletik yakni lari jarak pendek, lari jarak menengah - jauh, lompat, dan lempar yakni hasil menunjukkan masing-maisng nilai Sig. $>0.05$, maka dalam hal ini Ho diterima, dan dapat ditarik kesimpulan bahwa memiliki perbedaan yang berarti antara masing-masing aspek-aspek psikologi terhadap setiap kategori event.

Hal ini menjadi pertanyaan mengapa tidak terdapat perbedaan pada masing-masing. Hal ini dapat dikarenakan lingkungan atlet yang mempengaruhi kinerja pada masing-maisng nomor. Atlet atletik yang memiliki area latihan yang sama dengan pengaruh lingkungan yang sama ini juga dapat berdampak pada perkembanga karakteristik psikologi atlet. Hal ini juga dijelaskan oleh Daniel Gould dan Kristen Dieffenbach bahwa sejumlah individu dalam institusi mempengaruhi perkembangan psikologis atlet termasuk masyarakat, keluarga, individu itu sendiri, personel non-olahraga, personel lingkungan olahraga, dan proses olahraga(Gould, Dieffenbach, \& Moffett, 2002). Lingkungan olahraga serta proses olahraga ini dapat ditarik kesimpulan bahwa pada pembinaan yang dilakukan juga dapat mempengaruhi karakteristik psikologi dan terkait dengan keberhasilan atlet. Hal ini dicontohkan seperti cara-cara mengajar, memberikan suatu materi pelajaran psikologis tertentu dengan langsung atau tidak melibatkan pemodelan secara tidak sengaja menciptakan lingkungan psikologis tertentu.

Namun demikian setiap spesialisasi pada nomor Atletik juga harus dipertimbangkan faktor psikologis sesuai dengan kinerja mereka, tentunya hal ini diperlukan analisis terperinci dalam setiap kasus atau aspek (Dosil, 2006a), dan dalam penelitian ini telah menjelaskan bagaimana pada setiap nomor event memilikikarakteristik menonjol sebagai kelebihan dan kekurangan. Hal ini dapat menjadi masukan untuk dapat dilatih diperkuat dan dikembangkan menjadi lebih baik untuk meningkatkan kinerja Atlet Atletik UKM Universitas Negeri Semarang.

\section{KESIMPULAN}

Analisis perbedaan pada Atlet UKM Atletik UNNES memiliki terletak terhadap beberapa faktor yang menonjol sebagai kelemahan dan kelebihan dari masing-maisng nomor. Beberapa faktor psikologi yang telah didapatkan dari hasil penelitian tidak sepenuhnya kuat pada atlet UKM Atletik di UNNES. Ketika 




faktor terpenting dalam cabang olahraga atletik yaitu motivasi sudah terpenuhi maka pada faktor yang lain memerlukan latihan untuk dapat meingkatkan performa talet nantinya.

Dari hasil analisis multivariate diketahui tidak ada hubungan antara event lari jarak pendek, lari jarak menengah - jauh, lompat, dan lempar dengan karakteristik psikologis yang diukur, dan tidak terdapat perebedaan yang berarti pada setiap Aspek Psikologi yakni, confidence, anxiety control, motivation, mental preparation, concentration dan team emphasis terhadap setiap nomor dalam atletik.

Setiap atlet adalah individu yang berbeda, namun karakteristik dapat ditentukan pada usia, lingkungan hingga aktivitas yang atlet tersebut lakukan. Jika seorang atlet atletik pada nomor event tertentu memiliki faktor psikologi tertentu hal ini lah yang akan menjadi karakter dari atlet pada nomor event tersebut.

Penelitian ini menghasilkan gambaran tentang bahwa pada setiap nomor event memilikikarakteristik psikologi menonjol sebagai kelebihan ataupun kekurangan, beberapa faktor masih dalam kategori sedang dan kurang perlunya peningkatan latihan untuk memperbaiki karakeristik yang kirang dan mempertahankan apa yang sudah baik.

Dengan demikian perlunya studi lanjut yang berkaitan analisis terperinci dalam setiap kasus atau aspek untuk meningkatkan faktor psikologi atlet yang akan menjadi pengembangan yang lebih baik di bidang ini diperluka

Beberapa studi yang disarankan dari ropik ini yaitu :

- Studi karakteristik psikologi dari klub yang berbeda dengan sampel yang bervariasi dan jumlah yang seimbang sehingga dapat terlihat bagaimana karakteristik paling dominan khususnya pada olahraga Atletik.

- Pelatihan psikologi skill yang dapat diterapkan untuk atlet atletik untuk meingkatkan performa baik dalam latihan maupun dalam pertandingan

\section{REFERENSI}

Candra, A. R. D., Budiyanto, K. S., \& Sobihin. (2019). Psychological Characteristics of Athletes in Athletic Students Club Universitas Negeri Semarang, 362(Acpes), 13-17. https://doi.org/10.2991/acpes19.2019 .3

Dimyati, \& Hastuti, H. (2013). Karakteristik Psikologis Atlet di Pusat Pendidikan dan Latihan Pelajar ( PPLP ). Jurnal Psikologi $U G M, 40(2)$, 143-158. Retrieved from https://textid.123dok.com/document/y49m36rzkarakteristik-psikologis-atlet-di-pusatpendidikan-dan-latihan-pelajar-pplpdimyati-jurnal-psikologi-6973-27101-1pb.html

Dosil, J. (2006a). Applied Sport Psychology: A new Perspective. In J. Dosil (Ed.), The sport Psychologist's Handbook A guide for Sport Specific Performance Enhamcement (pp. 3-18). Retrieved from https://eeas.europa.eu/headquarters/headqua rters-homepage/8988/administrativeinformation-on-tenders_en

Dosil, J. (2006b). The Sport Psychologist's Handbook. (J. Dosil, Ed.), The Sport Psychologist's Handbook. Southern Gate, Chichester, Westr Sussex: John Wiley \& Sons Inc. https://doi.org/10.1002/9780470713174

Durand-Bush, N., \& Salmela, J. H. (2002). The development and maintenance of expert athletic performance: Perceptions of world and olympic champions. Journal of Applied Sport Psychology, 14(3), 154-171. https://doi.org/10.1080/1041320029010347 3

Galluci, N. T. (2014). SPORT PSYCHOLOGY Performance Enhancement, Performance Inhibition, Individuals and Teams (Second Edi). New York: Psychology Press 2008.

Gould, D., Dieffenbach, K., \& Moffett, A. (2002). 


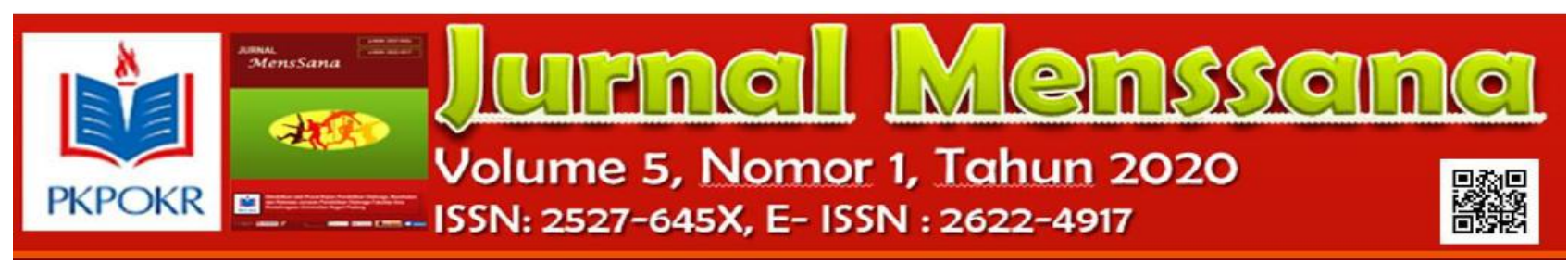

Psychological characteristics and their development in Olympic champions. Journal of Applied Sport Psychology, 14(3), 172-204.

https://doi.org/10.1080/1041320029010348 2

Mahoney, M. J., Gabriel, T. J., \& Perkins, T. S. (1988). Applied Rese. Psychology, 1, 1-12.

Maksum, A. (2007). Kualitas Pribadi Atlet: Kunci Keberhasilan Meraih Prestasi Tinggi. Anima, Indonesian Psychological Journal, 22(2), 108-115.

Mirzaei, A., Nikbakhsh, R., \& Sharififar, F. (2013). The relationship between personality traits and sport performance, 3(3), 439-442. Retrieved from www.pelagiaresearchlibrary.com Pelagia

Morris, T. (2010). Psychological characteristics and talent identification in soccer. Journal of Sports Sciences, $18(9$ desember 2010), 715-726.

https://doi.org/10.1080/0264041005012009 6

Nopiyanto, Y. E., \& Dimyati, D. (2018). Karakteristik psikologis atlet Sea Games Indonesia ditinjau dari jenis cabang olahraga dan jenis kelamin The psychological characteristics of Indonesian Sea Games athletes in terms of sports and sex. Jurnal Keolahragaan, 6(1), 69-76. Retrieved from http://dx.doi.org/10.21831/jk.v6i1.15010\% 0ACopyright

Sindik, J., Novokmet, N., \& Havas-Augustin, D. (2013). The application of psychological skills inventory for sports at Croatian coaches and recreational table tennis players. Sport Science 6, 1(June 2014), 5460.

Weinberg, R. S., \& Daniel, G. (2015). Foundation of Sport and Exercise Psychology (Sixth Edit). 